\title{
Studies on the nutritional properties of neem (Azadirachta indica) leaves at Pantnagar area of Uttarakhand
}

\section{S Kaushal, Anil Kumar, BS Khadda \& SB Bhardwaj}

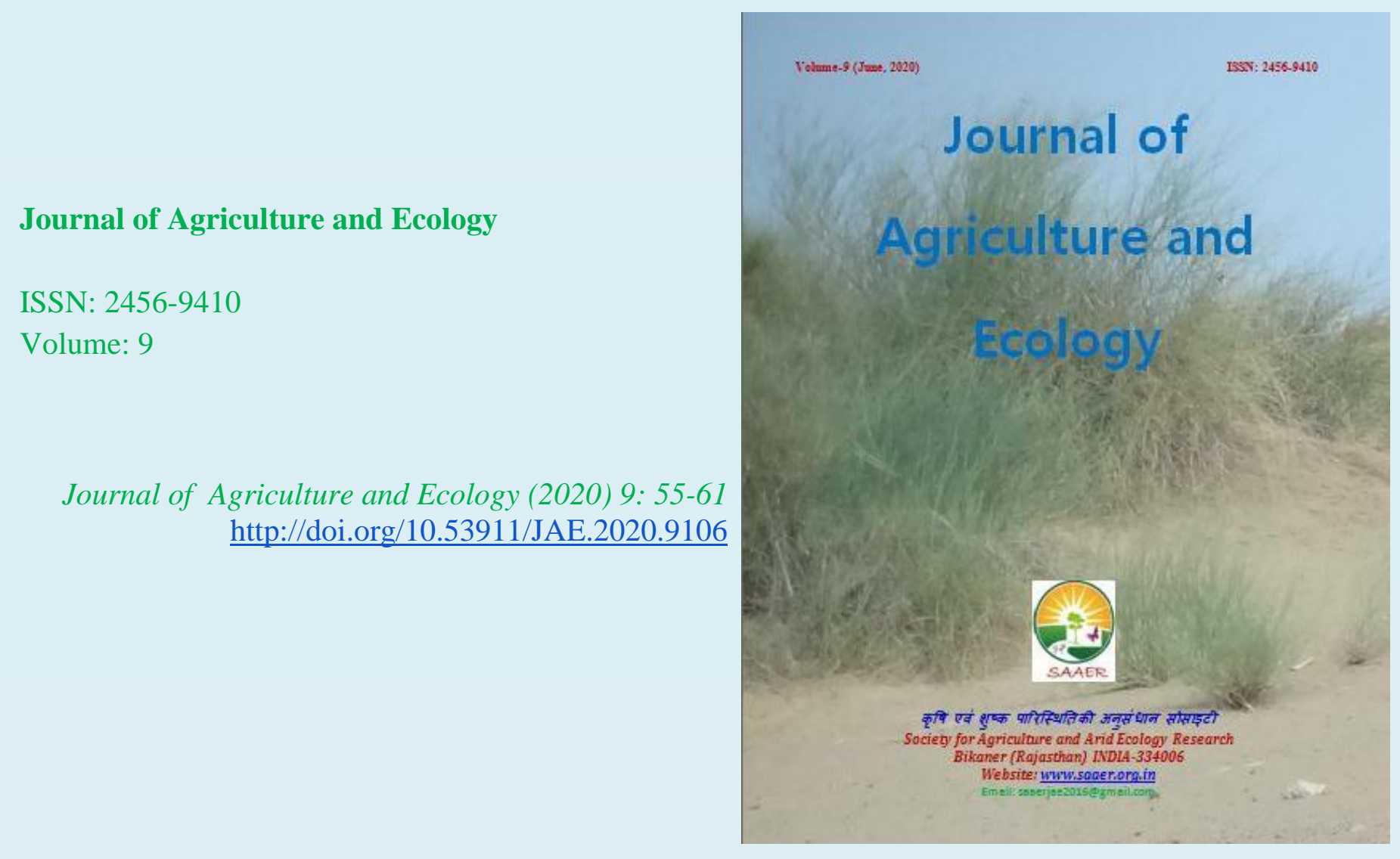




\title{
Studies on the nutritional properties of neem (Azadirachta indica) leaves at Pantnagar area of Uttarakhand
}

\author{
S Kaushal ${ }^{1} \square$, Anil Kumar ${ }^{2}$, BS Khadda ${ }^{3} \&$ SB Bhardwaj ${ }^{4}$ \\ ${ }^{l} V O$, Department of Animal Husbandry, UP \\ ${ }^{2}$ Associate Professor, Department of LPM CV \& ASc, GBPUA \& T, Pantnagar \\ ${ }^{3} S M S(A H), I C A R-K V K$, Panchmahals, Godhra, Gujarat \\ ${ }^{4}$ Statistician, Directorate of Experiment Station, GBPUA\&T Pantnagar \\ $\triangle$ Corresponding author: S Kaushal, dr.sandeep108@gmail.com
}

\section{Article Info}

Article history

Received: 20 May 2020

Accepted: 10 June 2020

Available online: 30 June 2020

Key Words: Neem (Azadirachta Indica) leaf powder, proximate analysis, dry matter.

\section{Abstract}

The present work was carried out to study the nutritional properties of neem (Azadirachta Indica) leaf powder collected from Pantnagar area. Equal quantity of neem leaves were collected from three different places such as College of Veterinary and Animal Science (C.V.A.Sc.), Instructional Poultry Farm (IPF) and Instructional Dairy Farm (IDF) inside the campus of G.B. Pant University of Agriculture and Technology Pantnagar. The leaves powder was prepared for proximate analysis i.e. Dry matter (DM), Crude Protein (CP), Ether Extract (EE), Total Ash (TA), Crude Fiber (CF), Calcium $(\mathrm{Ca})$ and Phosphorus $(\mathrm{P})$. Present study indicated that the neem leaf powder pre-pared from the leaves collected from Instructional Poultry Farm (IPF) have higher dry matter, crude protein and ether extract, whereas the value of calcium and phosphorus were found more in the leaves collected from College of Veterinary and Animal Science. So it can be concluded that neem leaf powder collected from Instructional Poultry Farm (IPF) can be included in the diet of the poultry for getting optimum results in growth performance, carcass characteristics, haematological, biochemical and immunological aspects.

Copyright (C2020 Kaushal et al., This is an open access article published under the terms of the Creative Commons Attribution License, which permits unrestricted use, distribution, and reproduction in any medium, provided the original work is properly cited.

Preferred citation: Kaushal S, Kumar A, Khadda BS \& Bhardwaj SB. 2020. Studies on the nutritional properties of neem (Azadirachta indica) leaves at Pantnagar area of Uttarakhand. Journal of Agriculture and Ecology, 9: 55-61; http://doi.org/10.53911/JAE.2020.9106.

\section{Introduction}

The medicinal plants and herbs have been used for many years in the treatment of various diseases in animals and human beings. Now-a-days, these are used in animal feed as growth promoters. Due to prohibition of most of the antimicrobial feed additives in animal feed and due to their residual effects in animals, plant extracts are becoming more popular. These feed additives act as antibacterial, antioxidant, anticarcinogenic, antifungal, analgesic, insecticidal, anticoccidial and growth promoters and these plant extracts compete with the synthetic drugs. Majority of medicinal plants do not have the residual effects. Azadirachta indica 
(neem) has the strong antibacterial activity, whereas leaves of Azadirachta indica are used for feeding and reducing the parasitic load in animals. Medicinal plants especially Withania somnifera (Ashwagandha) and Azadirachta indica (neem) can be used as growth promoters in the poultry diets with better production performance (Ansari et al. 2008). The fruit of Azadirachta indica also has the anticoccidial activity for poultry (Tipu et al. 2006). All parts of the neem tree- leaves, flowers, seeds, fruits, roots and bark have been used traditionally for the treatment of inflammation, infections, fever, skin diseases and dental disorders (Subapriya \& Nagini 2005). Neem contains several active ingredient like, nimbidin, gedunin, azadirachtin, mahmoodin, gallic acid, epicatechin and catachin, margalone, margolonone, cyclic trisulphide, polysaccharides and peptidoglycons which all contribute to its beneficial medicinal properties (Biswas et al. 2002). Neem leaves mainly yield quercetin (a polyphenolic flavonoid) and nimbosterol ( $\beta$ - sitosterol) as well as number of liminoids (nimbin and its derivatives). Neem also promotes growth and feed efficiency of birds because of its antibacterial and hepatoprotective properties (Padalwar 1994). Neem leaf and its constituents have been demonstrated to exhibit immunomodulatory, anti-inflammatory, antihyperglycaemic, antiulcer, antimalarial, antifungal, antibacterial, antiviral, antioxidant, antimutagenic and anticarcinogenic properties (Biswas et al. 2002, Subapriya \& Nagini 2005 and Bhowmik et al. 2010).

Keeping above characteristic of neem in consideration, the neem leaf powder (NLP) has been incorporated in the poultry diet by various workers but consistent results with respect to growth performance, carcass characteristics, haematological, biochemical and immunological aspects of neem leaf powder is lacking. Therefore, the present investigation was undertaken in view to evaluate the nutritional properties of neem leaves of Pantnagar area with an object to include them in the feed of livestock those are reared in different farms under the University.

\section{Material and Methods}

The present study was conducted at Instructional Poultry Farm (IPF), Nagla of College of Veterinary and Animal Sciences, Govind Ballabh Pant University of Agriculture and Technology, Pantnagar (U.S. Nagar), Uttarakhand. The place is located between $28^{\circ} 53^{\prime} 23^{\prime \prime}$ to $30^{\circ} 27^{\prime} 50^{\prime \prime} \mathrm{N}$ and $77^{\circ}$ $34^{\prime} 27^{\prime \prime}$ to $81^{\circ} 02$ ' $22^{\prime \prime} \mathrm{E}$ at $243.84 \mathrm{~m} \mathrm{MSL}$ in tarai region of Uttarakhand State (India).

The neem leaves samples were collected from the College of Veterinary and Animal Sciences (C.V.A.Sc.), Instructional Poultry Farm (I.P.F.) and Instructional Dairy Farm (I.D.F.) inside the campus of Govind Ballabh Pant University of Agriculture and Technology Pantnagar. They were shed dried/ dried at $55 \pm 1{ }^{0} \mathrm{C}$ to constant weight and ground to pass through a sieve of $1 \mathrm{~mm}$ diameter and stored in plastic containers. Deterioration of neem leaves occurs when it is stocked without proper drying. The major active principle in neem, azadirachtin, is highly heat sensitive. Neem leaves contain eight tetranortriterpenoids but apparently no azadirachtins. The experiments were conducted in the moisture range of 8.0 to 10.0 per cent (w.b.). The proximate analysis on dry 
matter basis of neem leaf powder used during experiment is presented in table 1 .

Analysis of Neem leaf powder feed and meat samples

The proximate analysis viz. moisture, crude protein, crude fibre, ether extract, total ash, $\mathrm{Ca}$ and $\mathrm{P}$ of neem leaf powder were determined as per the methods of AOAC (2005).

\section{Determination of Dry Matter}

Fresh sample was taken in the preweighted petri dish and kept in hot air oven at $100^{\circ} \mathrm{C}$ for 24 hrs. Dry matter was calculated as follows:

$$
\text { Dry matter }(\%)=\frac{\mathrm{b}}{\mathrm{a}} \times 100
$$

Where,

$$
\begin{aligned}
& a=\text { Fresh weight of sample }(\mathrm{g}) \\
& \mathrm{b}=\text { Weight of sample after drying }(\mathrm{g}) \\
& \text { Moisture }(\%)=100-\text { Dry matter }(\%)
\end{aligned}
$$

\section{Determination of Nitrogen and Crude Protein}

The protein content was determined by Kjeldahl method for the purpose $2 \mathrm{~g}$ of sample was taken in a digestion flask followed by addition of $3 \mathrm{~g}$ of digestion mixture $\left(\mathrm{K}_{2} \mathrm{SO}_{4}: \mathrm{CuSO}_{4}\right.$ in 9:1 ratio) and $20 \mathrm{ml}$ of conce sulphuric acid. The contents were digested till a blue/green transparent liquid was obtained. The digested mixture volume was made up to $100 \mathrm{ml}$ with distilled water. A $20 \mathrm{ml}$ aliquot of digested mixture was distilled with excess of 40 per cent $\mathrm{NaOH}$ solution and liberated ammonia was collected in $20 \mathrm{ml}$ of 2 per cent boric acid solution containing 2 to 3 drops of mixed indicator $(10 \mathrm{ml}$ of 0.1 per cent bromocresol green $+2 \mathrm{ml}$ of 0.1 per cent methyl red indicator in 95 per cent alcohol). The entrapped ammonia was titrated against $0.1 \mathrm{~N} \mathrm{HCl}$. A reagent blank was similarly digested and distilled. Nitrogen content in sample was calculated as follows:

$$
\mathrm{N} \%=\frac{\text { Sample Titre }- \text { Blank Titre } \times \text { Normality of } \mathrm{HCl} \times 14 \times \text { Volume made up }}{\text { Aliquot of digest taken } \times \text { Weight of sample taken }}
$$

Nitrogen was converted to per cent protein by multiplying with 6.25 .

\section{Determination of Ether Extract}

For estimation of ether extract Soxhlet method was used. In this method $2 \mathrm{~g}$ of dried and grinded sample was transferred to a thimble. Petroleum ether (B.P. $40-60^{\circ} \mathrm{C}$ ) was used as solvent which was subsequently evaporated. After 8 hours the thimble was taken out and it was weighed after complete drying in an oven at $60{ }^{\circ} \mathrm{C}$. Per cent ether extract in dried sample was calculated as follows, which was converted into wet basis by multiplying by a moisture factor.

Ether extract $(\%)=\frac{b}{a} \times 100$

where,

$$
\mathrm{a}=\text { weight } \text { of sample }
$$

$\mathrm{b}=$ (weight of oil flask after extraction)-

(weight of oil flask before extraction)

\section{Determination of Crude Fibre}

The dry sample after de-fatting was transferred from thimble to spoutless beaker of one litre capacity and in beaker; $200 \mathrm{ml}$ of 1.25 per cent $\mathrm{H}_{2} \mathrm{SO}_{4}$ was added. It was refluxed for 30 minutes on hot plate after the boiling started and thereafter, filtered through 
muslin cloth. The residue was washed 5-6 times with hot water until It became acid free. The residual material on the muslin cloth was again transferred to the respective beaker and in beaker $200 \mathrm{ml}$ of 1.25 per cent sodium hydroxide $(\mathrm{NaOH})$ solution was added. It was again refluxed for $30 \mathrm{~min}$. after the boiling started and thereafter filtered through muslin cloth and washed with hot water for 5-6 times until it became free from alkali. Thereafter, total residue was transferred in a clean, dry silica crucible and dried in hot air oven at $100^{\circ} \mathrm{C}$ for $24 \mathrm{hrs}$. Then, it was cooled in desiccator and weighed. The residue was then ignited in Muffle furnace at $600^{\circ} \mathrm{C}$ for $2 \mathrm{hrs}$. After $12 \mathrm{hrs}$ silica crucibles containing ash were removed from the furnace and transferred into desiccator, cooled and weighed again. Weight loss during ignition was recorded as the weight of crude fibre:

Crude fibre $(\%)$ on DM basis $=\frac{b-c}{a} \times 100$

Where,

$\mathrm{a}=$ weight of sample on DM basis $(\mathrm{g})$

$\mathrm{b}=$ weight of silica crucible before ignition $(\mathrm{g})$

$\mathrm{c}=$ weight of silica crucible containing residue after ignition $(\mathrm{g})$

\section{Determination of Total Ash}

$5 \mathrm{~g}$ of ground sample was taken in previously weighed silica crucible. The crucible along with sample was kept on a heater and burnt till no more smoke was given off by the charred mass of sample. Thereafter, the silica crucible containing charred mass of sample was transferred into muffle furnace with the help of metal tong and ignited at $600^{\circ} \mathrm{C}$ for $2 \mathrm{hrs}$. After $12 \mathrm{hrs}$, the crucible containing ash was removed from the furnace and then transferred into desiccator, cooled and weighed. Total ash was calculated as follows:

Total ash $(\%)$ on DM basis $=\frac{a-b}{c} \times 100$

Where,

$\mathrm{a}=$ weight of silica crucible with ash $(\mathrm{g})$

$\mathrm{b}=$ weight of empty silica crucible $(\mathrm{g})$

$\mathrm{c}=$ weight of sample taken for ashing on dry matter basis ( $\mathrm{g}$ )

\section{Estimation of Calcium}

For calcium estimation $10 \mathrm{ml}$ of hydrochloric acid extract was taken in a 100 $\mathrm{ml}$ beaker and 2-3 drops of methyl red indicator was added to it. Extract was heated to boiling, cooled and then $10 \mathrm{ml}$ of saturated ammonium oxalate solution was added slowly with constant stirring unit the precipitate became coarsely granular.

The contents were heated to boiling, cooled and then ammonium hydroxide (1: 4) was added till the colour became faint pink. The beaker was then kept overnight to settle the precipitate. The contents of beaker were then filtered through Whatman filter paper No. 40 leaving as much precipitate as possible in the beaker, the precipitates were than washed with hot water till they became free from soluble oxalates. The point of the filter paper was then broken with a glass rod and the precipitate were then washed into the beaker in which calcium was precipitated and dissolved in about $10 \mathrm{ml}$ of dilute sulphuric acid (1:9). The contents of beaker were heated to about $60^{\circ} \mathrm{C}$ and titrated against $\mathrm{N} / 10$ $\mathrm{KMnO}_{4}$. Finally, the filter paper was also kept in the beaker and the titration was completed. (Faint pink colour persisting for at least 30 seconds was indicative of complete titration). 


$$
\text { Calcium }(\%)=\frac{\mathrm{ml} \text { of } \mathrm{N} / 10 \mathrm{KMnO}_{4} \times 0.002 \times \text { volume of } \mathrm{HCl} \text { extract made }}{\text { wt.of sample taken for ashing } \times \text { aliquot taken }} \times 100
$$

\section{Estimation of Phosphorus}

For phosphorus estimation $10 \mathrm{ml}$ aliquot of $\mathrm{HCl}$ extract was taken into a $50 \mathrm{ml}$ volumetric flask and to it $5 \mathrm{ml}$ of $6.6 \%$ ammonium molybdate reagent was added. Water was then added to make the volume to $40 \mathrm{ml} .5 \mathrm{ml}$ of $7.5 \mathrm{~N} \mathrm{H}_{2} \mathrm{SO}_{4}$ was then added and mixed. After this $4 \mathrm{ml}$ ferrous sulphate reagent was mixed and volume was made up to the mark. Optical density was read immediately in spectrophotometer at $660 \mathrm{~nm}$.

\section{Statistical Analysis}

All the data expressed as Mean \pm SE were analyzed by using standard methods (Snedecor \& Cochran, 1994, Graph Pad Instat 2003).

\section{Results and Discussion}

The present study was undertaken in view to evaluate the nutritional properties of neem leaves of Pantnagar area reveal that the Dry matter (\%), Crude Protein (\%), Ether Extract (\%), Total Ash (\%), Crude Fiber (\%), Calcium (g) and Phosphorus (g) of neem leaf powder collected from College of Veterinary and Animal Science were found 88.02 \pm 0.03 , $21.22 \pm 0.05,2.34 \pm 0.04,9.85 \pm 0.01,7.80 \pm 0.09$, $1.88 \pm 0.05$ and $0.25 \pm 0.03$ respectively (Table $1)$. The Dry matter (\%), Crude Protein (\%), Ether Extract (\%), Total Ash (\%), Crude Fiber $(\%)$, Calcium (g) and Phosphorus ( $\mathrm{g}$ ) of neem leaf powder collected from Instructional Poultry Farm 90.66 $\pm 0.04, \quad 23.50 \pm 0.04$, $3.32 \pm 0.07,9.84 \pm 0.05,7.78 \pm 0.01,1.40 \pm 0.08$ and $0.20 \pm 0.02$ respectively (Table 1 ).

Table 1. Nutrients composition of neem leaf powder (NLP) collected from the various areas of GBPUAT, Pantnagar

\begin{tabular}{|c|c|c|c|}
\hline Particulars & $\begin{array}{l}\text { College of Veterinary } \\
\text { and Animal Science }\end{array}$ & $\begin{array}{l}\text { Instructional Poultry } \\
\text { Farm }\end{array}$ & $\begin{array}{l}\text { Instructional } \\
\text { Farm }\end{array}$ \\
\hline Dry Matter (\%) & $88.02 \pm 0.03$ & $90.66 \pm 0.04$ & $87.20 \pm 0.02$ \\
\hline Crude Protein $(\%)$ & $21.22 \pm 0.05$ & $23.50 \pm 0.04$ & $17.50 \pm 0.01$ \\
\hline Ether Extract (\%) & $2.34 \pm 0.04$ & $3.32 \pm 0.07$ & $2.50 \pm 0.06$ \\
\hline Total Ash (\%) & $9.85 \pm 0.01$ & $9.84 \pm 0.05$ & $9.90 \pm 0.07$ \\
\hline Crude Fiber (\%) & $7.80 \pm 0.09$ & $7.78 \pm 0.01$ & $7.85 \pm 0.03$ \\
\hline Calcium (g) & $1.88 \pm 0.05$ & $1.40 \pm 0.08$ & $1.14 \pm 0.08$ \\
\hline Phosphorus (g) & $0.25 \pm 0.03$ & $0.20 \pm 0.02$ & $0.19 \pm 0.04$ \\
\hline
\end{tabular}

Similarly, The Dry matter $(\%)$, Crude Protein (\%), Ether Extract (\%), Total Ash (\%), Crude Fiber (\%), Calcium (g) and Phosphorus (g) of neem leaf powder collected from Instructional Dairy Farm 87.20 \pm 0.02 , $17.50 \pm 0.01,2.50 \pm 0.06,9.90 \pm 0.07,7.85 \pm 0.03$,
$1.14 \pm 0.08$ and $0.19 \pm 0.04$ respectively (Table 1).

Present study indicate that NLP collected from the Instructional Poultry Farm has higher percentages of dry matter, crude protein and ether extract, whereas the values of calcium 
and phosphorus were found to be higher than leaves collected from college of Veterinary and Animal Sciences and lower than leaves collected from Instructional Dairy Farm of University. There were no significant different with respect to the values of total ash and crude fibre contents of different NLPs. Singh et al. (2014) reported that NLP collected from the Instructional Poultry Farm, Pantnagar, University has higher percentages of dry matter, crude protein and ether extract. The poultry production is feed which may account up to $70 \%$ of total production cost. Commercial livestock require nutritionally balance diet. Various feed additives or growth promoters have been incorporated to improve production performance (growth rate and feed efficiency) and to reduce the production cast. Present study indicate that inclusion of NLP prepared from the leaves collected from the IPF in the livestock getting optimum result in growth performance, haematological,

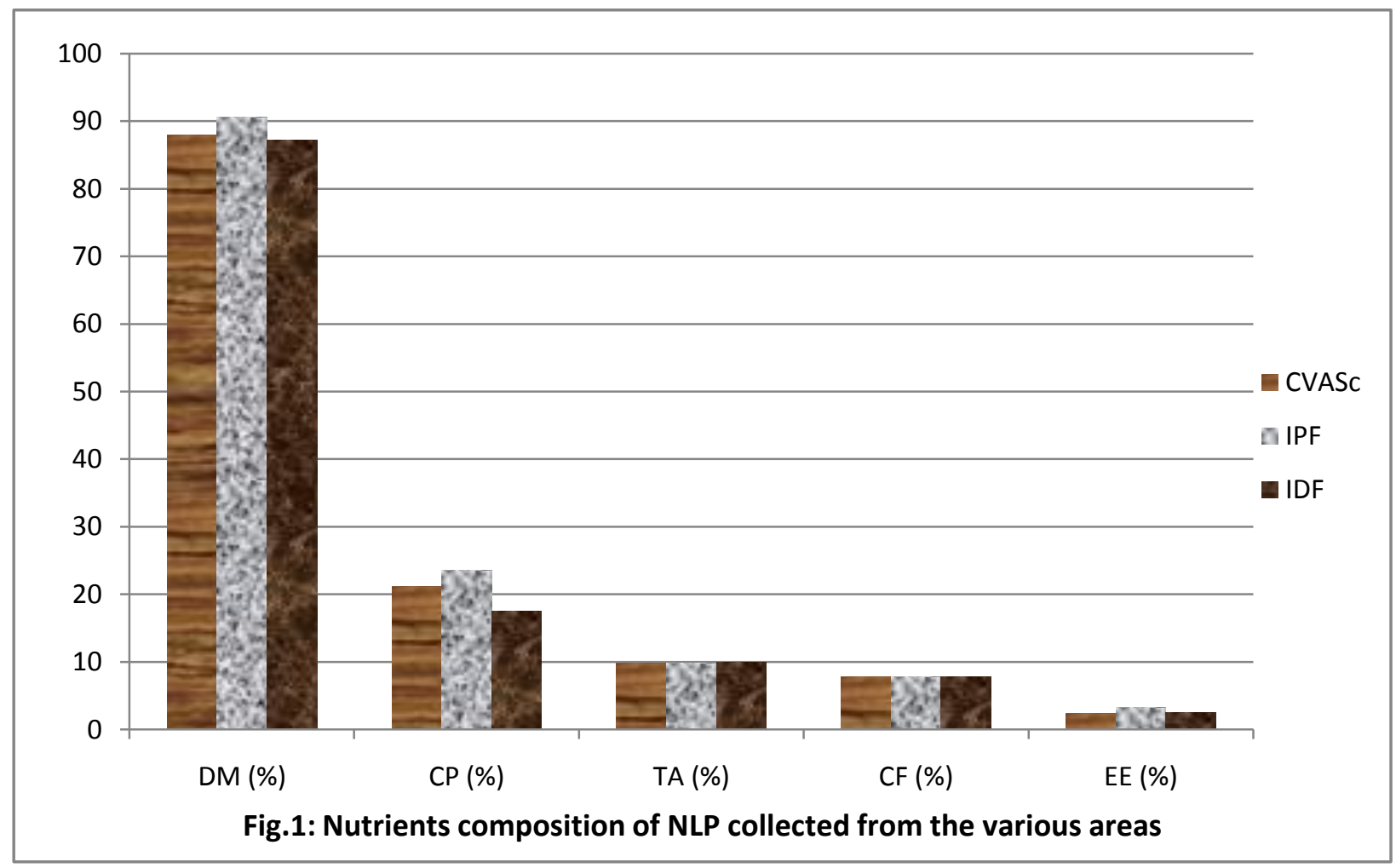

biggest single expense in any system of biochemical and carcass parameters.

\section{Conclusion}

Present study related to nutritional properties of neem leaf powder indicated that the neem leaf powder pre-pared from the leaves collected from Instructional Poultry Farm (IPF) have higher dry matter, crude protein and ether extract in comparison of NLP of collected from College of Veterinary and Animal Science and Instructional Dairy Farm. The results conclusively indicated that neem leaf powder collected from Instructional Poultry Farm (IPF) can be included in the diet of the poultry for getting optimum results in growth performance, carcass characteristics, haematological, biochemical and immunological aspects. 


\section{Acknowledgement}

Authors are thankful to the Director, Experiment Station and Dean, College of Veterinary and Animal Sciences, G.B. Pant University of Agriculture and Technology, Pantnagar Pantnagar for providing necessary facilities to conduct the research experiment.

\section{Reference}

Ansari JZ, Haq A, Yousa M, Ahmad T \& Khan S. 2008. Evaluation of different medicinal plants as growth promoters for broiler chicks. Sarhad J. Agri., 24(2): 323-29.

AOAC. 2003. Official methods of analysis, $17^{\text {th }}$ Edn. $2^{\text {nd }}$ revision, Association of official Analytical Chemist. Gaithersburg, MD, USA.

Bhowmik D, Yadav CJ, Tripathi KK \& Sampath KP. 2010. Herbal remedies of Azadirachta indica and its medicinal application. J. Chem. Pharm. Res., 2(1): 62-72.

Biswas K, Chattopadhyay I, Banarjee RK and Bandyopadhyay U. 2002. Biological activities and medicinal properties of neem (Azadirachta indica).Current Sci. Rev., 82(11): 1336-45.

Graph Pad Instat. 2003. Demo version. GraphPad software Inc. San Digeo. In: www.graphpad.com.

Padalwar RV. 1994. Neem (Azadirachta indica) leaves as feed supplement in broiler ration. Unpublished M.V.Sc Thesis submitted to Dr.Punjabrao Deshmukh Krishi Vidyapeth, Akola.

Singh M K, Singh SK \& Sathapathy S. 2014. Studies on the nutritional evaluation of neem leaves of Pantnagar area. Inter. Nati. J. Scien. Res., 3 (9): 445-47

Snedecor GW and Cochran W B. 1994. Statistical methods. $8^{\text {th }}$ Edn. The Iowa State University Press, Ames, IOWA, USA.

Subapriya R and Nagini S. 2005. Medicinal properties of neem leaves. Current Med. Chem. Rev., 5(2):149-156.

Tipu MA, Akhtar MS, Anjum MI \& Raja ML. 2006. New dimension of medicinal plants as animal feed. Pakistan Vet. J., 26 (3): 144-48. 